\title{
PENINGKATAN KEMAMPUAN GURU DALAM PERENCANAAN DAN PELAKSANAAN PEMBELAJARAN MATEMATIKA MELALUI SUPERVISI AKADEMIK DENGAN TEKNIK KUNJUNGAN KELAS
}

\author{
DARWIN SIREGAR \\ Pengawas Sekolah Dinas Pendidikan Kecamatan Silangkitang \\ Email: darwinsiregar168@gmail.com
}

\begin{abstract}
Abstrak: Penelitian ini bertujuan untuk meningkatkan kemampuan guru dalam perencanaan dan pelaksanaan pembelajaran matematika melalui supervisi akademik dengan teknik kunjungan kelas di SD Negeri 114361 Binanga Dua Semester II Tahun Pelajaran 2018/2019. Subjek penelitian tindakan sekolah ini adalah 6 guru di SD Negeri 114361 Binanga Dua yang terdiri dari guru kelas I sampai dengan kelas VI. Pengumpulan data dilakukan dengan cara observasi dan dokumentasi. Analisis data yang digunakan dalam penelitian ini adalah statistik deskriptif. Peningkatan aspek perencanaan pembelajaran meningkat dari 50,91 pada kondisi awal menjadi 68,48 pada siklus pertama dan 85,76 pada siklus kedua, sehingga disimpulkan bahwa pada siklus kedua dinyatakan berhasil karena sudah memenuhi kriteria keberhasilan yaitu masuk dalam kriteria nilai minimal baik, sedangkan peningkatan kemampuan dalam pelaksanaan proses pembelajaran, yaitu dari 50,58 pada kondisi awal menjadi 69,83 pada siklus pertama dan 86,67 pada siklus kedua, sehingga disimpulkan bahwa pada siklus kedua dinyatakan berhasil karena sudah memenuhi kriteria keberhasilan yaitu masuk dalam kriteria nilai minimal baik. Maka dapat ditarik kesimpulan bahwa pelaksanaan supervisi akademik dengan teknik kunjungan kelas terbukti dapat meningkatan kemampuan guru dalam perencanaan dan pelaksanaan pembelajaran matematika guru-guru SD Negeri 114361 Binanga Dua Semester II Tahun Pelajaran 2018/2019.
\end{abstract}

Kata kunci: perencanaan, pelaksanaan pembelajaran, kunjungan kelas

\begin{abstract}
This study aims to improve the ability of teachers in planning and implementing mathematics learning through academic supervision with class visit techniques in Public Elementary Schools 114361 Binanga Dua Semester II Academic Year 2018/2019. The action research subjects of this school are 6 teachers in Public Elementary School 114361 Binanga Dua consisting of class I to class VI teachers. Data collection is done by observation and documentation. The data analysis used in this study is descriptive statistics. Increased aspects of learning planning increased from 50.91 in the initial conditions to 68.48 in the first cycle and 85.76 in the second cycle, so it was concluded that in the second cycle it was declared successful because it had met the criteria of success, which was included in the criteria of minimum value, while increasing ability in the implementation of the learning process, namely from 50.58 in the initial conditions to 69.83 in the first cycle and 86.67 in the second cycle, so it was concluded that in the second cycle it was declared successful because it had met the criteria of success, which was included in the criteria of minimum value. Then it can be concluded that the implementation of academic supervision with class visit techniques is proven to be able to improve the ability of teachers in planning and implementing mathematics learning teachers of Public Elementary Schools 114361 Binanga Dua Semester II Academic Year 2018/2019.
\end{abstract}

Keyword: planning, implementing learning, class visits

Peraturan Menteri Pendidikan Nasional Republik Indonesia Nomor 16 tahun 2007 tentang Standar Kualifikasi Akademik dan Kompetensi Guru menyebutkan bahwa kompetensi guru sekolah dasar meliputi kompetensi pedagogik, kompetensi kepribadian, kompetensi sosial, dan kompetensi profesional. Salah satu kompetensi di atas yaitu 
kompetensi pedagogik khususnya kemampuan guru dalam mengembangkan kurikulum yang terkait dengan mata pelajaran pada kelas yang diampu. Kompetensi pedagogik tersebut sangat relevan dengan salah satu kewajiban guru sesuai dengan Peraturan Pemerintah Nomor 74 tentang Guru pasal 52 ayat (1) mencakup kegiatan pokok guru yaitu merencanakan pembelajaran, melaksanakan pembelajaran, menilai hasil pembelajaran, membimbing dan melatih peserta didik serta melakukan tugas tambahan yang melekat pada pelaksanaan tugas pokok. Selain itu kewajiban pendidik adalah menciptakan suasana pembelajaran yang aktif, kreatif, efektif dan menyenangkan.

Guru hakekatnya adalah sebuah jabatan profesi yang dalam kiprahnya membutuhkan suatu keahlian khusus dibidangnya, memiliki komitmen dan tanggung jawab moral dalam mengantar para peserta didik pada dunia kehidupan yang lebih dewasa dan berguna bagi semua, memiliki kecintaan, keikhlasan kepedulian pada profesi yang diembannya. Menurut UU Guru dan Dosen Nomor 14 tahun 2005 Pasal 1 Ayat 1 dinyatakan bahwa "Guru adalah pendidik profesional dengan tugas utama mendidik, mengajar, membimbing, mengarahkan, melatih, menilai dan mengevaluasi peserta didik pada pendidikan anak usia dini jalur pendidikan formal, pendidikan dasar dan pendidikan menengah".

Upaya profesionalisme jabatan guru memang berkaitan erat dengan upaya meningkatkan kualitas pembelajaran dan hasil belajar siswa, artinya bahwa peningkatan hasil belajar siswa ditentukan oleh kualitas pembelajaran dan kualitas guru atau profesionalisme guru. Perencanaan pembelajaran merupakan bagian penting dalam pelaksanaan pendidikan. Melalui perencanaan yang baik, guru akan lebih mudah dalam melaksanakan pembelajaran dan siswa akan lebih terbantu dan mudah dalam belajar. Perencanaan pembelajaran dikembangkan sesuai dengan kebutuhan dan karakteristik peserta didik, kondisi sekolah, mata pelajaran, dan kondisi lingkungan. Setiap guru pada satuan pendidikan berkewajiban menyusun rencana pelaksanaan pembelajaran (RPP) secara lengkap dan sistematis agar pembelajaran berlangsung secara interaktif, inspiratif, menyenangkan, menantang, memotivasi peserta didik untuk berpartisipasi aktif. Perencanaan menyangkut penetapan tujuan dan kompetensi serta memperkirakan cara mencapainya. Menurut Mulyasa (2009:77) perencanaan merupakan fungsi sentral dari manajemen pembelajaran dan harus berorientasi ke masa depan.

Untuk itu perencanaan pembelajaran harus disesuaikan dengan target pendidikan yang telah ditentukan. Guru sebagai subyek dalam perencanaan dituntut untuk dapat menyusun berbagai program pengajaran sebagai pendekatan dan metode yang akan digunakan. Dalam buku "Perencanaan Pembelajaran" yang diterbitkan oleh Departemen Pendidikan Nasional Direktorat Jenderal Pendidikan Dasar dan Menengah Direktorat Tenaga Kependidikan tahun 2004 disebutkan bahwa: Perencanaan pembelajaran (instruction design) adalah keseluruhan proses analisis kebutuhan dan tujuan belajar serta pengembangan sistem penyampaiannya untuk memenuhi kebutuhan dan mencapai tujuan belajar, termasuk didalamnya pengembangan paket pembelajaran dan kegiatan mengevaluasi program dan hasil belajar.

Matematika merupakan salah satu matapelajaran yang mempunyai peranan penting dalam pendidikan. Sebagaimana yang dikemukakan oleh Saselah, Jaeng \& Sugita (2018:59) bahwa matematika perlu diajarkan kepada siswa mulai dari Sekolah Dasar (SD) hingga ke jenjang Perguruan Tinggi (PT). Oleh karenanya dalam merencanakan dan melaksanakan pembelajaran matematika guru perlu senantiasa meningkatkan kemampuannya sehingga sejak dini siswa dapat lebih terarah dalam proses belajarnya. Pembelajaran sejatinya adalah aktivitas guru dalam merancang bahan pengajaran agar 
proses pembelajaran yang dilakukan dapat membuat siswa belajar secara aktif dan bermakna (Siregar \& Aristantiya, 2017:49). Siregar \& Surya (2017:144) mengemukakan bahwa: Teaching and learning activities conducted in the school certainly have a goal to be achieved. To achieve these objectives then the learning must be implemented in accordance with the standard of education process. Artinya, kegiatan belajar mengajar yang dilakukan di sekolah tentu memiliki tujuan yang ingin dicapai. Untuk mencapai tujuan tersebut maka pembelajaran harus dilaksanakan sesuai dengan standar proses pendidikan. Selain itu salah satu keputusan yang perlu diambil guru tentang pembelajaran adalah pemilihan pendekatan dan strategi yang digunakan (Suaidin, 2014:35). Tentunya pemilihan pendekatan dan strategi ini termasuk ke dalam tahap perencanaan pembelajaran yang selanjutnya akan dilaksanakan dalam kegiatan belajar mengajar.

Pembelajaran dan pengembangan sepenuhnya menjadi tugas dan kreativitas dari guru yang mengajar di kelas, guru dituntut memiliki kreativitas yang tinggi karena dengan menggunakan Kurikulum Tingkat Satuan Pendidikan (KTSP) sekolah diberi keleluasaan untuk membuat strategi pembelajaran sendiri dalam menyampaikan mata pelajaran sesuai dengan kurikulum yang telah ditentukan kepada siswa disesuaikan dengan situasi dan kondisi di sekolah masing-masing. Untuk itu masing-masing sekolah berusaha untuk meningkatkan kualitas pembelajaran dengan sebaik-baiknya tanpa mengurangi esensi dan substansi dari kurikulum yang ada. Di dalam pembelajaran ada 3 komponen yang harus dikembangkan dan saling keterkaitan yaitu guru, siswa dan proses pembelajaran. Dari pihak guru adalah guru harus terlebih dahulu membuat perencanaan pembelajaran yang matang mulai dari membuat program tahunan, program semester, dan program harian yang berupa Rencana Pelaksanaan Pembelajaran (RPP) disamping harus menguasai materi yang akan diajarkan, metode-metode mengajar dan bisa menguasai kelas serta membuat alat evaluasi. Dari pihak siswa kesiapan menerima pelajaran, kedisiplinan dan kesungguhan, sedangkan proses pembelajaran adalah ada suatu sinergi antara guru, murid, metode dan model pembelajaran yang tepat dari materi kompetensi yang akan diajarkan.

Salah satu faktor utama dalam meningkatkan kemampuan guru adalah dengan adanya supervisi akademik. Istilah supervisi secara umum dikenal dari bahasa Inggris "supervision", yang artinya mengawasi, atau atasan yang menilai kinerja bawahan. Supervisi dapat diartikan sebagai bentuk pelayanan, bantuan profesional, atau bimbingan bagi guru-guru dan dengan melalui pertumbuhan kemampuan guru yang hendak meningkatkan mutu pendidikan dan pengajaran (Sutisna, 1993:71).

Berkaitan dengan istilah supervisi, Mulyasa (2003:42) menjelaskan bahwa dalam pelaksanaannya sering digunakan secara bergantian dengan istilah pengawasan, pemeriksaan, dan inspeksi. Pengawasan dapat diartikan sebagai proses untuk menjamin bahwa tujuan-tujuan organisasi dan manajemen tercapai (Reksohadiprodjo, Sukanto \& Handoko, 1992:31). Pengawasan juga dapat diartikan suatu kegiatan untuk melakukan pengamatan agar pekerjaan dilakukan sesuai dengan ketentuan. Pemeriksaan dimaksudkan untuk melihat suatu kegiatan yang dilaksanakan telah mencapai tujuan. Sedangkan inspeksi dimaksudkan untuk mengetahui kekurangan kekurangan atau kesalahan yang perlu diperbaiki dalam suatu pekerjaan.

Berbeda dengan Sutisna (1993:79) yang menjelaskan bahwa secara umum supervision diberi arti sama dengan direction atau pengawasan dan ada kecenderungan untuk membatasi pemakaian istilah supervisor pada orang-orang yang berada dalam kedudukan yang lebih bawah dalam hirarki manajemen. Kedudukan yang setingkat dengan supervisor adalah manajer lini pertama (first line management), pengawas, atau mandor. Secara lebih khusus, Sutisna (1993:49) mengartikan supervisi sebagai bantuan dalam 
mengembangkan situasi belajar mengajar yang lebih baik. Dengan perkataan lain, supervisi adalah suatu kegiatan pembelajaran yang disediakan untuk membantu para guru untuk meningkatkan kemampuan dalam menjalankan tugas pengajaran. Peran supervisor adalah membantu, memotivasi dan mendukung guru agar semakin matang (mature) dan mandiri dalam menjalankan tugas utamanya.

Mulyasa (2003:27) mengemukakan bahwa tujuan supervisi adalah mengembangkan iklim yang kondusif dan lebih baik dalam kegiatan pembelajaran, melalui pembinaan dan peningkatan profesi mengajar. Dengan kalimat lain, tujuan supervisi pengajaran adalah membantu dan memberikan kemudahan kepada para guru untuk belajar meningkatkan kemampuan mereka guna mewujudkan tujuan belajar peserta didik. Secara lebih operasional, tujuan supervisi menurut Ametembun (Mulyasa, 2003:32) adalah (1) membina kepala sekolah dan guru agar lebih memahami tujuan pendidikan, (2) meningkatkan kemampuan kepala sekolah dan guru-guru untuk mempersiapkan peserta didik menjadi anggota masyarakat yang lebih efektif, (3) membantu kepala sekolah dan guru mengadakan diagnosis secara kritis terhadap aktivitas kerja, persoalan pembelajaran, serta membantu merencanakan perbaikan-perbaikan, (4) meningkatkan kesadaran kepala sekolah dan guruguru serta petugas sekolah lainnya terhadap cara kerja yang demokratis, serta kesediaan untuk tolong-menolong, (5) memperbesar semangat guru-guru dan meningkatkan motivasi berprestasi, (6) membantu kepala sekolah untuk mensosialisasikan program pendidikan di sekolah kepada masyarakat, (7) melindungi warga sekolah yang disupervisi terhadap tuntutan yang tidak wajar dan kritik-kritik yang tidak sehat dari masyarakat, (8) membantu kepala sekolah dan guru-guru dalam mengevaluasi aktivitasnya untuk mengembangkan kreativitas peserta didik, (9) mengembangkan rasa kesatuan (kolegialitas) sesama guru.

Supervisi pendidikan berperan memberikan kemudahan dan membantu kepala sekolah dan guru mengembangkan potensi secara optimal. Supervisi harus dapat meningkatkan kepemimpinan kepala sekolah sehingga dapat mencapai efektivitas dan efisiensi program sekolah secara keseluruhan. Melalui supervisi, guru diberi kesempatan untuk meningkatkan kinerja, dilatih untuk memecahkan berbagai permasalahan yang dihadapi.

Supervisi mempunyai fungsi ganda, untuk meningkatkan kemampuan mengajar guru dan untuk pengembangan kurikulum. Burton (Oliva, 1984: 16) mengidentifikasi fungsi supervisi sebagai berikut: "(1) The improvement of the teaching act, (2) The improvement of teachers in service, (3) The selection and organization of subject matter, (4) Testing and measuring, and (5) The rating of teachers". Sedangkan Oliva sendiri membagi fungsi supervisi menjadi tiga yaitu, pengembangan staf (staff development), pengembangan kurikulum (curriculum development), dan perbaikan pengajaran (instructional development). Selanjutnya secara makro, Sutisna (1993:88) berpendapat bahwa fungsi supervisi adalah (1) sebagai penggerak perubahan, (2) sebagai program pelayanan untuk memajukan pengajaran, (3) meningkatkan kemampuan hubungan manusia, dan (4) sebagai kepemimpinan kooperatif.

Adapun yang dimaksud dengan supervisi kunjungan kelas adalah salah satu pendekatan supervisi individual. Supervisi kunjungan kelas adalah kegiatan kepala sekolah/pengawas sekolah mengunjungi kelas tempat guru sedang melaksanakan pembelajaran (Sahertian \& Mataheru, 1985:45). Kepala sekolah maupun pengawas dalam melaksanakan supervisi kepada guru di kelas dilengkapi dengan lembar observasi/kuesioner yang dijadikan alat ukur keberhasilan guru dalam membelajarkan siswa. Teknik kunjungan kelas merupakan salah satu dari sekian banyak teknik supervisi pendidikan. Teknik ini dapat dikategorikan sebagai teknik supervisi yang bersifat indiviual, karena secara praktis, 
dilaksanakan oleh supervisor secara perorangan dalam upaya membina dan mengembangkan kemampuan guru dikelas. Istilah "membina" dimaksudkan sebagai bentuk bantuan yang diberikan supervisor kepada guru yang dianggap mengalami kesulitan dalam menjalankan tugasnya. Sedangkan istilah "mengembangkan" dimaksudkan sebagai bentuk bantuan terhadap guru dalam menjalankan tugasnya terutama berhubungan dengan adanya suatu program baru dalam konteks pembelajaran.

Pendapat yang hampir sama dikemukakan oleh Sutisna (1993:68) bahwa supervisi kunjungan kelas adalah pengamatan yang dilakukan oleh kepala sekolah atau pengawas terhadap guruyang sedang mengajar dan melihat alat, metode, dan sarana belajar lainnya di kelas. Aspek yang diamati oleh supervisor di kelas tidak hanya kegiatan guru dalam membelajarkan siswa, akan tetapi termasuk sarana yang diperlukan untuk mendukung kegiatan pembelajaran antara lain media, ketepatan metode pembelajaran dengan materi pelajaran, termasuk ketersediaan bahan ajar lainnya. Supervisi kunjungan kelas dilaksanakan melalui tahapan atau langkah-langkah tertentu agar pelaksanaan dapat berjalan lancar dan mencapai target yang di tentukan. Langkah-langkah supervisi kunjungan kelas meliputi, (1) tahap persiapan, (2) tahap pelaksanaan, (3) tahap evaluasi.

Berdasarkan uraian diatas, maka kemampuan guru harus selalu ditingkatkan mengingat tantangan dunia pendidikan untuk menghasilkan kualitas sumber daya manusia yang mampu bersaing di era global semakin ketat. Kemampuan guru (performance) merupakan hasil yang dicapai oleh guru dalam melaksanakan tugas-tugas yang dibebankan kepadanya yang didasarkan atas kecakapan, pengalaman dan kesungguhan serta penggunaan waktu. Upaya-upaya untuk meningkatkan kinerja itu biasanya dilakukan dengan cara memberikan motivasi disamping cara-cara yang lain. Akan tetapi pada kenyataannya proses pembelajaran yang dilakukan oleh guru belum maksimal sesuai apa yang diharapkan. Hal itu berdasarkan hasil penjajagan yang telah dilakukan oleh peneliti dimana permasalahan yang muncul atau mengemuka ke permukaan antara lain: 1) Lemahnya pengelolaan, pengorganisasian dan pengembangan proses pembelajaran yang dilakukan oleh guru, 2) Cara belajar siswa masih bersifat klasikal dimana siswa masih sebatas mendengarkan dan melihat bahan ajar yang disampaikan guru, 3) Penyampaian bahan ajar yang dilakukan oleh guru masih bersifat klasikal maupun verbalisme, 4) Keterbatasan kemampuan guru dalam mengaplikasikan bahan ajar melalui metode maupun media pembelajaran yang ada dan 5) Minimnya pengetahuan guru dalam penggunaan metode maupun media pembelajaran dalam penyampaian bahan ajar. Selain dari permasalahan guru, berdasarkan hasil identifikasi dan pengamatan langsung yang dilakukan oleh peneliti di lapangan dimana penelitian yang peneliti lakukan juga bersumber dari permasalahan-permasalahan yang dihadapi siswa di lapangan (di sekolah). Adapun permasalahan yang muncul dari siswa antara lain: 1) Rendahnya hasil belajar siswa pada mata pelajaran matematika jika dibandingkan dengan hasil belajar mata pelajaran lain seperti IPA, IPS maupun bahasa Indonesia, dan 2) Rendahnya kreativitas siswa dalam proses berfikir serta orang tua pada umumnya kurang dapat merangsang maupun memotivasi siswa untuk giat dalam belajar hal itu desebabkan oleh tingkat pendidikan orang tua yang cukup rendah sehingga menyebabkan rendahnya hasil belajar siswa tersebut. Oleh karena itu maka dibutuhkan upaya dalam peningkatan kemampuan guru dalam perencanaan dan pelaksanaan pembelajaran matematika melalui supervisi akademik dengan teknik kunjungan kelas di SD Negeri 114361 Binanga Dua Semester II Tahun Pelajaran 2018/2019. 


\section{METODE PENELITIAN}

Peneltian yang digunakan adalah Penelitian Tindakan Sekolah (PTS) dan dilaksanakan dalam 2 siklus. Setiap siklus terdiri dari dua kali pertemuan. Masing masing siklus (Sanjaya, 2011:91-92) terdiri dari tahap perencanaan (planning), tindakan (action), observasi (observation), dan tahap refleksi (reflection). Penjelasan secara ringkas tentang tahapan-tahapan dalam pelaksanaan kegiatan penelitian tindakan sekolah ini sebagaimana dijelaskan pada bagan di bawah ini.

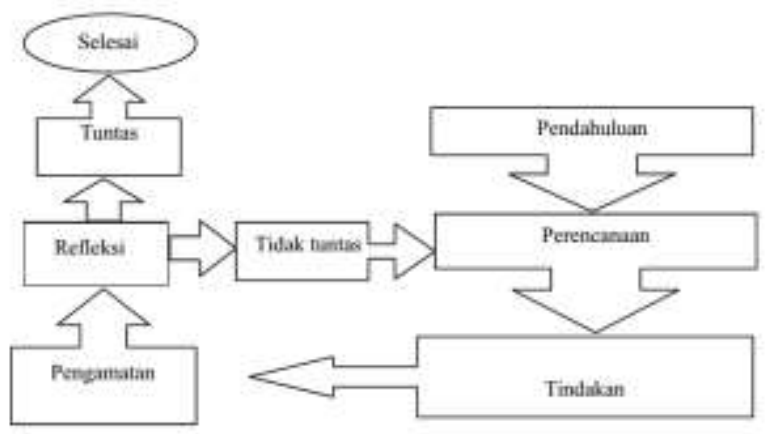

Gambar 1. Siklus dalam penelitian tindakan sekolah (Arikunto, 2006:16)

Pendekatan yang digunakan dalam penelitian ini adalah pendekatan deskriptif. Subjek penelitian tindakan sekolah ini adalah 6 guru di SD Negeri 114361 Binanga Dua UPT Dinas Pendidikan Kecamatan Silangkitang Kabupaten Labuhabatu pada Semester II Tahun Pelajaran 2018/2019 yang terdiri dari guru kelas I sampai dengan kelas VI. Pengumpulan data dilakukan dengan cara observasi dan dokumentasi.

\section{HASIL PENELITIAN}

Berdasarkan data hasil penelitian ini diketahui bahwa penilaian kemampuan guru pada perencanaan dan pelaksanaan kegiatan pembelajaran dilaksanakan melalui 2 siklus yaitu: Siklus I dilaksanakan dalam 2 kali pertemuan, pada pertemuan 1 setelah selesai diadakan refleksi, dan diperoleh data bahwa penentuan materi ajar, menentuan indikator keberhasilan dan menentukan sumber belajar masih kurang dari target keberhasilan pada penelitian ini, maka untuk materi yang masih kurang dilanjutkan pada pertemuan 2, setelah selesai pertemuan 2 diadakan refleksi untuk menentukan apakah masih perlu ada pertemuan 3 atau tidak. Siklus II dilaksanakan dalam 2 kali pertemuan, pada pertemuan 1 setelah selesai pengamatan diadakan refleksi, dan diperoleh data bahwa dalam kegiatan inti yaitu belum merencanakan kegiatan yang bisa mengaktifkan siswa dalam hal ini menentukan model pembelajaran, demikian juga dalam menentukan aspek penilaian masih ditemukan belum adanya kesesuaian antara materi pembelajaran dengan bentuk soal yang dibuat termasuk dalam menentukan skor penilaian. Dengan telah ditemukan kekurangan pada pertemuan 1 ini, maka untuk materi yang masih kurang dilanjutkan pada pertemuan 2, setelah selesai pada pertemuan 2 hasilnya dikumpulkan, diteliti dan dianalisa, setelah itu diadakan refleksi untuk menentukan pada tahap berikutnya. Selanjutnya, menganalisis hasil-hasil penilaian yang dilakukan terhadap kemampuan guru pada kegiatan pembinaan tentang perencanaan dan pelaksanaan pembelajaran pada masing-masing siklus apakah 
semakin membaik atau malah sebaliknya serta menentukan langkah dan tindakan selanjutnya.

Secara jelas dan rinci peningkatan kemampuan guru khususnya guru kelas I s.d VI pada penilaian perencanaan dan pelaksanaan pembelajaran sebagaimana tabel di bawah ini.

Tabel 1. Rekapitulasi Hasil Penilaian Perencanaan Pembelajaran pada Kondisi Awal, Siklus Pertama dan Kedua

\begin{tabular}{|c|c|c|c|c|c|}
\hline \multirow[t]{2}{*}{ No } & \multirow[t]{2}{*}{ Nama Guru } & \multicolumn{3}{|c|}{ Siklus / Nilai } & \multirow[t]{2}{*}{ Ket } \\
\hline & & Awal & I & II & \\
\hline 1 & Guru Kls 1 & 40,00 & 61,82 & 80,00 & \\
\hline 2 & Guru Kls 2 & 56,36 & 65,45 & 83,64 & \\
\hline 3 & Guru Kls 3 & 56,36 & 76,36 & 85,45 & \\
\hline 4 & Guru Kls 4 & 52,73 & 72,73 & 92,73 & \\
\hline 5 & Guru Kls 5 & 43,64 & 61,82 & 80,00 & \\
\hline 6 & Guru Kls 6 & 56,36 & 72,73 & 92,73 & \\
\hline & Jumlah & 305,45 & 410,91 & 514,55 & \\
\hline & Rata-Rata & 50,91 & 68,48 & 85,76 & \\
\hline
\end{tabular}

Dalam bentuk grafik peningkatan hasil pembinaan dengan melaksanaan kegiatan penilaian kemampuan guru dalam merencanakan kegiatan pembelajaran tersaji pada grafik berikut ini.

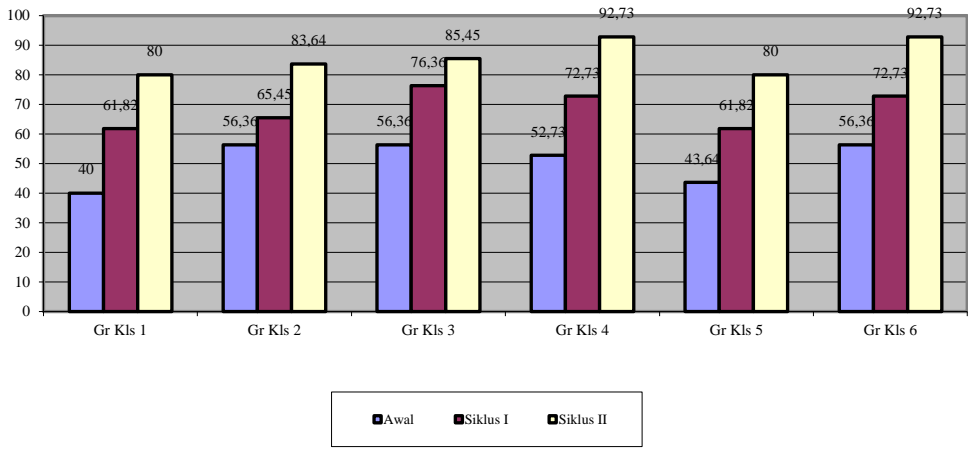

Gambar 2. Peningkatan penilaian hasil kemampuan guru aspek perencanaan pembelajaran pada kondisi awal, siklus pertama dan kedua

Adapun penjelasan mengenai peningkatan nilai rata-rata secara klasikal pada penilaian perencanaan pembelajaran sebagaimana dijelaskan pada grafik di bawah ini.

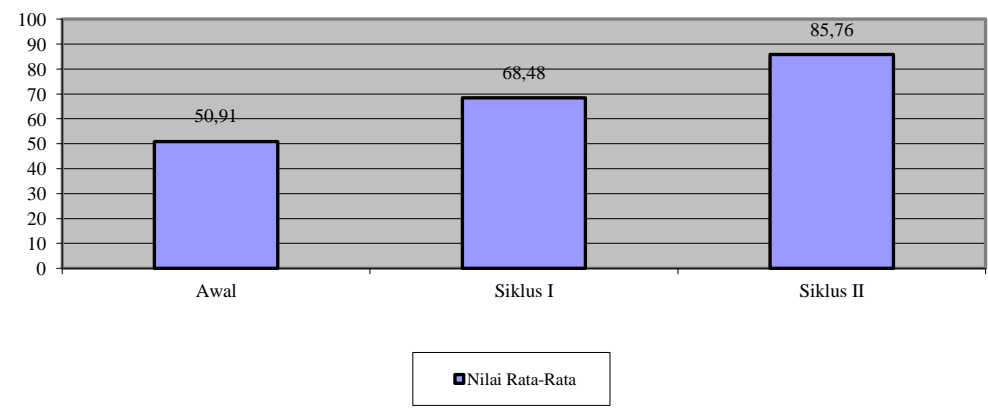

Gambar 3. Peningkatan nilai rata-rata aspek perencanaan pembelajaran pada kondisi awal, siklus pertama dan kedua 
Dari gambar di atas dapat dijelaskan bahwa penilaian kemampuan guru pada aspek perencanaan pembelajaran meningkat dari 50,23 pada kondisi awal menjadi 68,48 pada siklus pertama dan 85,76 pada siklus kedua, sehingga disimpulkan bahwa pada siklus kedua dinyatakan berhasil karena sudah memenuhi kriteria keberhasilan yaitu masuk dalam kriteria nilai minimal baik.

Adapun penjelasan mengenai peningkatan kemampuan guru dalam pelaksanaan proses pembelajaran sebagaimana dijelaskan di bawah ini.

Tabel 2. Rekapitulasi Hasil Penilaian Pelaksanaan Proses Pembelajaran pada Kondisi Awal, Siklus Pertama dan Kedua

\begin{tabular}{|c|c|c|c|c|c|}
\hline No & \multirow{2}{*}{$\begin{array}{c}\text { Nama } \\
\text { Guru }\end{array}$} & \multicolumn{3}{|c|}{ Siklus / Nilai } & \multirow{2}{*}{ Ket } \\
\cline { 3 - 5 } & & Awal & I & II & \\
\hline 1 & Guru Kls 1 & 55,50 & 75,50 & 81,00 & \\
2 & Guru Kls 2 & 40,00 & 62,00 & 82,00 & \\
3 & Guru Kls 3 & 55,50 & 71,00 & 91,00 & \\
4 & Guru Kls 4 & 49,00 & 70,50 & 90,50 & \\
5 & Guru Kls 5 & 48,00 & 67,00 & 88,00 & \\
6 & Guru Kls 6 & 55,50 & 73,00 & 87,50 & \\
\hline \multicolumn{7}{|c|}{ Jumlah } & $\mathbf{3 0 3 , 5 0}$ & $\mathbf{4 1 9 , 0 0}$ & $\mathbf{5 2 0 , 0 0}$ & \\
\hline & Rata-Rata & $\mathbf{5 0 , 5 8}$ & $\mathbf{6 9 , 8 3}$ & $\mathbf{8 6 , 6 7}$ & \\
\hline
\end{tabular}

Dalam bentuk grafik peningkatan hasil pembinaan dengan melaksanaan kegiatan penilaian kemampuan guru dalam pelaksanaan kegiatan pembelajaran tersaji pada grafik berikut ini.

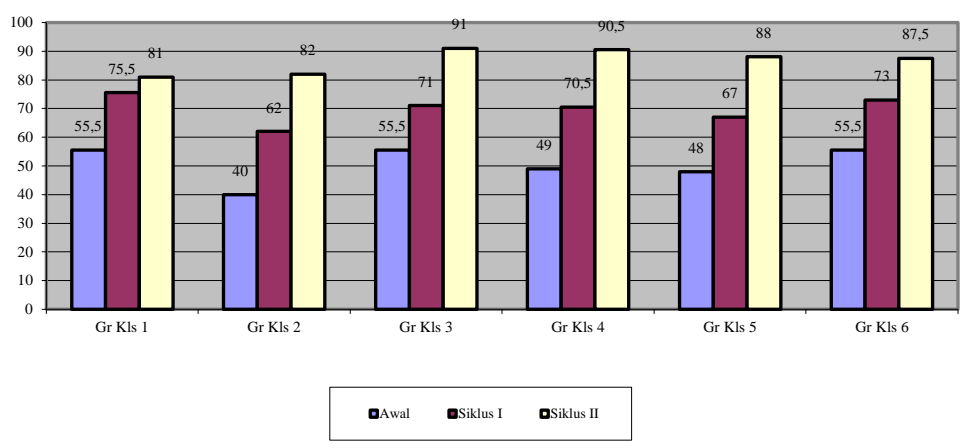

Gambar 4. Peningkatan penilaian hasil kemampuan guru aspek pelaksanaan proses pembelajaran pada kondisi awal, siklus pertama dan kedua

Adapun penjelasan mengenai peningkatan nilai rata-rata secara klasikal pada penilaian pelaksanaan proses pembelajaran di masing-masing kelas sebagaimana dijelaskan pada grafik berikut ini. 


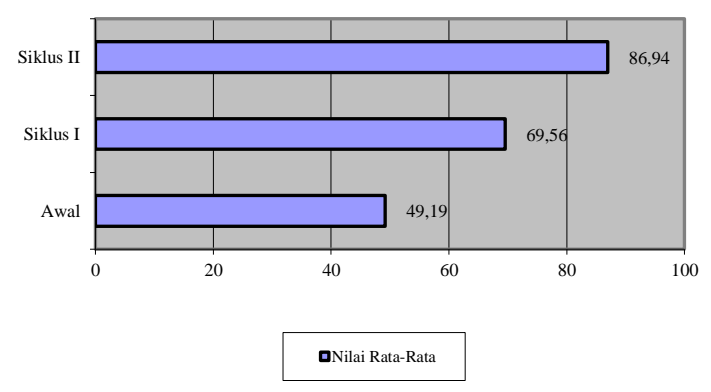

Gambar 5. Peningkatan nilai rata-rata aspek pelaksanaan proses pembelajaran pada kondisi awal, siklus pertama dan kedua

Dari gambar di atas dapat dijelaskan bahwa penilaian kemampuan guru pada aspek pelaksanaan proses pembelajaran meningkat dari 50,58 pada kondisi awal menjadi 69,83 pada siklus pertama dan 86,67 pada siklus kedua, sehingga disimpulkan bahwa pada siklus kedua dinyatakan berhasil karena sudah memenuhi kriteria keberhasilan yaitu masuk dalam kriteria nilai minimal baik.

\section{PEMBAHASAN}

Penelitian ini dilaksanakan di SD Negeri 114361 Binanga Dua Semester II Tahun Pelajaran 2018/2019. Berdasarkan hasil penelitian diperoleh bahwa penilaian kemampuan guru pada aspek perencanaan pembelajaran meningkat dari 50,23 pada kondisi awal menjadi 68,48 pada siklus pertama dan 85,76 pada siklus kedua, sehingga disimpulkan bahwa pada siklus kedua dinyatakan berhasil karena sudah memenuhi kriteria keberhasilan yaitu masuk dalam kriteria nilai minimal baik. Sedangkan untuk penilaian kemampuan guru pada aspek pelaksanaan proses pembelajaran meningkat dari 50,58 pada kondisi awal menjadi 69,83 pada siklus pertama dan 86,67 pada siklus kedua, sehingga disimpulkan bahwa pada siklus kedua dinyatakan berhasil karena sudah memenuhi kriteria keberhasilan yaitu masuk dalam kriteria nilai minimal baik. Hal ini menunjukkan bahwa setelah dilakukan tindakan melalui supervisi akademik dengan teknik kunjungan kelas maka kemampuan guru dalam perencanaan dan pelaksanaan pembelajaran dapat meningkat.

Sejalan dengan hasil penelitian ini terdapat beberapa penelitian lainnya yang relevan diantaranya penelitian Zainuddin (2016:212) yang memperoleh hasil: yaitu (Pra Siklus); tidak ada guru dengan kategori Sangat Baik, 1 orang Baik, 7 orang Cukup, dan 2 orang Kurang Baik. (Siklus 1); 5 guru berada pada kategori baik, dan 5 orang Cukup. (Siklus 2); 3 orang guru Sangat Baik, 6 orang guru Baik, 1 orang Cukup dan tidak ada lagi guru yang berada pada kategori Kurang Baik. Jurotun, Samsudi \& Prihatin (2015:27) dalam penelitiannya memperoleh hasil bahwa model supervisi akademik terpadu valid dan efektif untuk meningkatkan kompetensi pedagogik guru matematika. Sulistyaningsih (2015:19) dari hasil penelitiannya menyimpulkan bahwa supervisi akademik dapat meningkatkan kinerja guru dalam melaksanakan pembelajaran matematika pada semester I di SD Negeri Pagojengan 01 tahun pelajaran 2013/2014, dibuktikan dengan peningkatan nilai matematika dari kondisi awal mengalami peningkatan pada siklus 1 dan siklus 2. Selanjutnya hasil penelitian Brotosedjati (2012:229) menunjukkan bahwa: 1) ada pengaruh yang signifikan supervisi kunjungan kelas oleh kepala sekolah terhadap kinerja guru, 2) ada pengaruh yang 
signifikan kompensasi terhadap kinerja guru, dan 3) secara bersama-samaada pengaruh yang signifikan supervisi kunjungan kelas oleh kepala sekolah dan kompensasi terhadap kinerja guru.

Peneliti memilih model penilaian kemampuan guru dengan harapan terjadi kontrak antara kepala sekolah dan guru, karena dalam pola penilaian kemampuan guru ada kedaulatan yang seimbang antara kepala sekolah dan guru, yang memiliki tanggung jawab masing-masing sama-sama sedang. Tugas pokok kepala sekolah mencakup: mendengarkan, mempresentasikan, memecahkan masalah dan negosiasi. Dalam pembahasan ini peneliti sampaikan langkah-langkah yang telah dilakukan dalam rangka pembinaan guru tentang peningkatan kemampuan guru dalam perencanaan dan pelaksanaan pembelajaran melalui kegiatan kunjungan kelas.

Dengan mendengarkan semua kesulitan-kesulitan yang dihadapi oleh guru, yaitu tentang perencanaan dan pelaksanaan pembelajaran yang meliputi kegiatan-kegiatan penyusunan pengembangan silabus dan pengembangan Rencana Pelaksanaan Pembelajaran (RPP) guru-guru merasa mendapatkan perhatian dan kesulitannya didengar sehingga menjadi lebih terbuka untuk mengemukakan kesulitannya masing-masing. Kesulitankesulitan yang dihadapi guru diinventarisir dan diolah, setelah itu kepala sekolah mempresentasikan tentang pentingnya membuat perencanaan pembelajaran sendiri yang sesuai dengan kompetensi yang ingin dicapai agar tahu persis apa yang akan dilakukan sesuai dengan situasi dan kondisi serta sarana dan prasarana yang tersedia.

Dengan demikian guru menyadari kekeliruannya selama ini, yang hanya memfotokopi silabus dan RPP dan itupun hanya dikumpulkan pada wakil kepala sekolah urusan kurikulum, belum dijadikan sebagai pedoman dalam mengajar. Setelah guru menyadari kekeliruannya selama ini, mereka ingin mencoba menyusun pengembangan silabus dan RPP sendiri dan bersedia untuk diadakan pembinaan secara klasikal dan berdasarkan kesepakatan diadakan dua kali yang pertama tentang penyusunan pengembangan silabus dan yang kedua penyusunan pengembangan rencana pelaksanaan pembelajaran. Selain itu, kepala sekolah memberikan motivasi agar sebelum mengajar sudah menyusun pengembangan pembelajaran yang dibuat sendiri sehingga pada pelaksanaan pembelajaran lebih percaya diri, terprogram dan sesuai dengan situasi dan kondisi sekolah serta sarana dan prasarana yang tersedia serta untuk memenuhi tuntutan kompetensi profesionalisme dan kompetensi pedagogik seorang pendidik,dengan demikian tujuan akhir adalah prestasi siswa baik.

Dari hasil penelitian ini diperoleh adanya peningkatan kemampuan guru guru-guru dalam membuat perencanaan dan pelaksanaan pembelajaran meliputi penyusunan pengembangan silabus dan Rencana Pelaksanaan Pembelajaran (RPP) setelah diberikan pembinaan dengan pelaksanaan penilaian kemampuan guru di SD Negeri 114361 Binanga Dua.

\section{KESIMPULAN}

Berdasarkan analisis data di atas penulis mengambil kesimpulan bahwa dengan kegiatan penilaian melalui pelaksanaan kegiatan kunjungan kelas terhadap kemampuan guru dalam merencanakan dan melaksanakan kegiatan pembelajaran oleh kepala sekolah pada guru-guru di SD Negeri 114361 Binanga Dua terbukti dapat meningkatkan kemampuan guru dalam merencanakan dan melaksanakan kegiatan pembelajaran. Hal tersebut dapat dibuktikan dengan adanya peningkatan hasil penilaian terhadap aspek perencanaan dan aspek pelaksanaan pembelajaran oleh masing-masing guru. Terdapat 
peningkatan kemampuan guru menyusun perencanaan pembelajaran sebelum ada penilaian kinerja dan setelah dilaksanakan penilaian kemampuan guru pada aspek perencanaan pembelajaran meningkat dari 50,91 pada kondisi awal menjadi 68,48 pada siklus pertama dan 85,76 pada siklus kedua, sehingga disimpulkan bahwa pada siklus kedua dinyatakan berhasil karena sudah memenuhi kriteria keberhasilan yaitu masuk dalam kriteria nilai minimal baik. Terdapat peningkatan kemampuan guru kegiatan pelaksanaan pembelajaran sebelum ada penilaian kemampuan dan setelah dilaksanakan penilaian kemampuan guru dalam pelaksanaan proses pembelajaran, yaitu dari 50,58 pada kondisi awal menjadi 69,83 pada siklus pertama dan 86,67 pada siklus kedua, sehingga disimpulkan bahwa pada siklus kedua dinyatakan berhasil karena sudah memenuhi kriteria keberhasilan yaitu masuk dalam kriteria nilai minimal baik.

\section{REFERENSI}

Arikunto, S. (2006). Prosedur Penelitian Suatu Pendekatan Praktik. Jakarta: Rineka Cipta.

Brotosedjati, S. (2012). "Pengaruh supervisi kunjungan kelas oleh kepala sekolah dan kompensasi terhadap kinerja guru SD Negeri di Kecamatan Sukoharjo," Jurnal Pendidikan dan Kebudayaan, vol.18, no. 3, pp. 229-243.

Depdiknas. (2004). Perencanaan Pembelajaran. Direktorat Jenderal Pendidikan Dasar dan Menengah Direktorat Tenaga Kependidikan.

Depdiknas. (2005). Undang-Undang Republik Indonesia Nomor 14 Tahun 2005 tentang Guru dan Dosen. Depdiknas: Jakarta.

Depdiknas. (2007). Peraturan Menteri Pendidikan Nasional Republik Indonesia, Nomor 16 Tahun 2007 tentang Standar Kualifikasi Akademik dan Kompetensi Guru. Jakarta: Depdiknas.

Depdiknas. (2008). Peraturan Pemerintah Republik Indonesia Nomor 74 Tahun 2008 tentang Guru. Depdiknas: Jakarta.

Jurotun, Samsudi \& Prihatin, T. (2015). " Model supervisi akademik terpadu berbasis pemberdayaan mgmp untuk meningkatkan kompetensi pedagogik guru matematika," Jurnal Penelitian Tindakan Sekolah dan Pengawasan, vol. 2, no. 1, pp. 27-34.

Mulyasa, E. (2009). Menjadi Guru Profesional Menciptakan Pembelajaran Kreatif dan Menyenangkan. Bandung: Remaja Rosdakarya.

Mulyasa. (2003). Kepala Sekolah Profesional. Bandung: PT Remaja Rosdakarya.

Oliva, P.F.(1984). Supervision for Todays School. New York: Tomas J. Crowell Company.

Reksohadiprodjo, Sukanto \& Handoko, T.H. (1992). Organisasi Perusahaan: Teori, Struktur dan Perilaku. Yogyakarta. BPFE

Sahertian, P.A., \& Mataheru, F. (1985). Prinsip dan Teknik Supervisi Pendidikan. Surabaya: Usaha Nasional

Sanjaya, W. (2011). Penelitian Tindakan Kelas. Jakarta: Kencana. 
Saselah, N., Jaeng, M., \& Sugita, G., "Penerapan model pembelajaran penemuan terbimbing untuk meningkatkan hasil belajar siswa SMP Negeri 6 Palu pada materi pertidaksamaan linear satu variabel," AKSIOMA Jurnal Pendidikan Matematika, vol. 7, no. 1 , pp. 58-72, 2018.

Siregar, A.F., \& Aristantiya, N., "Upaya meningkatkan hasil belajar matematika dengan model pembelajaran kooperatif tipe think pair share (tps)," Seminar Nasional Matematika: Peran Alumni Matematika dalam Membangun Jejaring Kerja dan Peningkatan Kualitas Pendidikan, Fakultas Matematika Universitas Negeri Medan, 2017.

Siregar, A.F., \& Surya, E., "Perception of mathematics teachers against implementation of curriculum 2013," International journal of sciences: Basic and Applied Research (IJSBAR), vol. 33, no. 2, pp. 144-155. 2017.

Suaidin, "Upaya meningkatkan kemampuan guru dalam menerapkan strategi pembelajaran "think-talk-write" sebagai alternatif pemecahan masalah matematika pada wilayah SMA Binaan di Kabupaten Dompu melalui supervisi kolaboratif," AKSIOMA Jurnal Pendidikan Matematika, vol. 03, no. 01, pp. 35-43, 2014.

Sulistyaningsih, A. (2015). "Peningkatan kinerja guru dalam pembelajaran matematika melalui supervisi akademik SD Negeri Pagojengan 01 semester I tahun pelajaran 2013/2014," Dialektika P. Matematika, vol. 2, no. 2, pp. 19-26.

Sutisna, O. (1993). Administrasi Pendidikan Dasar Teoritis untuk Praktek Profesional, Bandung: Angkasa.

Zainuddin. (2016). "Supervisi akademik dapat meningkatkan kompetensi guru melaksanakan proses pembelajaran," Jurnal Pendidikan Serambi Ilmu, vol. 25, no. 2, pp. 212-219. 